\title{
APLIKASI TEORI BILANGAN DALAM PERMAINAN NIM
}

\section{(APPLICATION OF NUMBER THEORY IN THE NIM GAME)}

\author{
Benny Yong', Caesar Stefanus ${ }^{2}$, Vincent Hari $^{3}$ \\ ${ }^{1}$ Universitas Katolik Parahyangan, benny_y@unpar.ac.id \\ 2evan0396@gmail.com \\ ${ }^{3}$ vincent_harys@yahoo.com
}

\begin{abstract}
Abstrak
Di dunia ini terdapat banyak permainan yang berhubungan dengan Matematika, misalkan permainan kartu bridge, domino, catur, NIM, dan masih banyak lagi. Permainan NIM adalah suatu permainan strategi yang dimainkan oleh dua pemain dimana setiap pemain secara bergantian mengambil paling sedikit satu objek dengan aturan-aturan tertentu. Kemenangan permainan ini bergantung pada berapa banyak objek yang tersedia dan siapa yang bermain dahulu. Makalah ini akan menyajikan empat buah permainan NIM; NIM Maksima, NIM SatuEmpat, NIM Satu-Tiga-Empat, dan NIM Satu-Tiga-Lima-Tujuh. Pada permainan NIM ini, peranan Matematika dalam hal ini teori bilangan adalah menentukan suatu strategi untuk memenangkan permainan.
\end{abstract}

Kata kunci: permainan NIM, strategi, kongruensi

\begin{abstract}
In this world, there are many games related to Mathematics, for example bridge card, dominoes, chess, NIM, and many more. NIM game is a strategy game played by two players in which each player took turns in taking at least one object with certain rules. The victory of this game depends on how many objects are available and who is playing first. This paper will present four games of NIM; NIM Maxima, NIM One-Four, NIM One-Three-Four, and NIM One-ThreeFive-Seven. In this NIM game, the contribution of Mathematics especially number theory is to determine a strategy for winning the game.
\end{abstract}

Keywords: NIM game, strategy, congruence

\section{PENDAHULUAN}

Permainan adalah suatu kegiatan rekreasi yang biasanya dilakukan oleh 2 orang atau lebih. Dalam memainkan permainan, terdapat strategi khusus untuk memenangkan permainan tersebut. Di dalam makalah ini, akan dibahas suatu strategi dalam memenangkan permainan NIM.

Permainan NIM merupakan permainan klasik yang mengandalkan strategi sebagai elemen utamanya (Silbernick \& Campbell, 2015). Permainan NIM berasal dari China, nama ini berasal dari kata "NIMM" yang dalam bahasa Jerman artinya adalah "mengambil" (Burcham, 2013). NIM merupakan suatu jenis permainan yang telah ada selama berabad-abad di seluruh dunia dan orang Eropa yang pertama mereferensikan permainan ini pada abad ke-15. NIM adalah suatu permainan yang dimainkan oleh 2 orang dengan suatu aturan tertentu. Ada berbagai jenis permainan NIM. Pada makalah ini akan disajikan empat buah 
permainan NIM, yaitu NIM Maksima, NIM Satu-Empat, NIM Satu-Tiga-Empat, dan NIM Satu-Tiga-Lima-Tujuh.

Untuk keempat permainan NIM yang akan dibahas disini, akan ditentukan suatu strategi untuk memenangkan permainan tersebut. Teori Matematika yang tampak pada permainan ini adalah tentang teori bilangan. Konsep teori bilangan, khususnya kongruensi akan dipakai dalam pembentukan strategi kemenangan ini. Dari uraian pada makalah ini dapat terlihat bahwa konsep teori bilangan dapat diaplikasikan dalam permainan NIM. Jadi, tujuan yang akan disampaikan pada makalah ini adalah mengaplikasikan konsep teori bilangan dalam menentukan suatu strategi kemenangan pada permainan NIM Maksima, NIM Satu-Empat, NIM Satu-Tiga-Empat, dan NIM Satu-Tiga-Lima-Tujuh, sebelum permainan NIM dimulai dengan kondisi dan aturan yang telah ditetapkan sebelumnya.

\section{BAHASAN UTAMA \\ Permainan}

Sesuatu dapat dikatakan sebuah permainan jika memiliki ciri-ciri umum sebagai berikut (Arifin, 2010):

a. Memiliki 2 pemain

b. Kesempatan bermain bergantian

c. Kerugian seorang pemain adalah keuntungan bagi pemain lain

d. Pemain mengetahui seluruh informasi dari permainan

e. Tidak mengandung unsur peluang seperti pada permainan dadu

\section{Kongruensi}

Menurut Burton (2010), $a$ dikatakan kongruen $b$ modulo $m$ (ditulis sebagai $a \equiv b \bmod m$ ), jika $a$ mempunyai sisa bagi yang sama dengan $b$ ketika $a$ dan $b$ keduanya dibagi dengan $m$. Contohnya: $4 \equiv 0 \bmod 2,24 \equiv 17 \bmod 7$, dan $3 \equiv-5 \bmod 8$.

\section{Strategi Kemenangan NIM Maksima}

Misalkan kita memiliki $M$ benda dan banyaknya mengambil benda pada setiap giliran sebanyak maksimum $N$, dimana $M>N, M, N \in \mathbb{Z}^{+}$. Terdapat dua pemain (namakanlah pemain A dan B) dengan 21 benda tersedia di atas meja. Setiap pemain pada gilirannya mengambil maksimal 3 benda. Permainan ini dapat dibagi menjadi 2 jenis permainan yaitu, pemain terakhir yang mengambil sisa benda adalah pemain yang menang dan pemain terakhir yang mengambil sisa benda adalah pemain yang kalah. Berikut adalah contoh jalannya permainan yang dilakukan oleh kedua pemain.

Tabel 1. Ilustrasi Permainan NIM Maksima 21 Benda dengan Pemain Terakhir yang Mengambil Sisa Benda adalah Pemenang (A Mulai Dahulu, A Pemenang)

\begin{tabular}{|c|c|c|c|}
\hline \multicolumn{2}{|c|}{$\mathrm{A}$} & \multicolumn{2}{|c|}{$\mathrm{B}$} \\
\hline Benda diambil & Sisa benda & Benda diambil & Sisa benda \\
\hline 1 & 20 & 2 & 18 \\
\hline 2 & 16 & 3 & 13 \\
\hline 1 & 12 & 1 & 11 \\
\hline 3 & 8 & 2 & 6 \\
\hline 2 & 4 & 3 & 1 \\
\hline 1 & 0 & & \\
\hline
\end{tabular}


Dari 21 benda, A sebagai pemain pertama mengambil 1 benda, sehingga tersisa 20 benda. B sebagai pemain kedua mengambil 2 benda sehingga sisa benda menjadi 18. Demikian seterusnya dapat dilihat pada Tabel 1 bahwa pemain A memenangkan permainan.

Tabel 2. Ilustrasi Permainan NIM Maksima 20 Benda dengan Pemain Terakhir yang Mengambil Sisa Benda adalah Pemain yang Menang (A Mulai Dahulu, B sebagai Pemenang)

\begin{tabular}{|c|c|c|c|}
\hline \multicolumn{2}{|c|}{$\mathrm{A}$} & \multicolumn{2}{|c|}{ B } \\
\hline Benda diambil & Sisa benda & Benda diambil & Sisa benda \\
\hline 1 & 19 & 3 & 16 \\
\hline 1 & 15 & 3 & 12 \\
\hline 3 & 9 & 1 & 8 \\
\hline 2 & 6 & 2 & 4 \\
\hline 1 & 3 & 3 & 0 \\
\hline
\end{tabular}

Dari 20 benda, A sebagai pemain pertama mengambil 1 benda, sehingga tersisa 19 benda. B sebagai pemain kedua mengambil 3 benda sehingga sisa benda menjadi 16. Demikian seterusnya dapat dilihat pada Tabel 2 bahwa pemain B memenangkan permainan.

Dari kedua ilustrasi di atas, akan dibentuk suatu strategi untuk memenangkan permainan NIM Maksima dengan pemain terakhir yang mengambil sisa benda adalah pemain yang menang. Perhatikan 2 kasus berikut ini.

1. Kasus $N+1 \nmid M(N+1$ tidak membagi $M)$

Dalam kasus ini, pemain pertama akan memenangkan permainan. Sebagai giliran pertama, kita dapat mengambil benda sehingga tersisa kelipatan $(N+1)$ benda untuk diambil lawan, atau banyaknya benda yang tersisa kongruen $0 \bmod (N+1)$. Kita tahu lawan akan mengambil sebanyak $1,2,3, \ldots, N$ benda. Sisa benda yang tersedia yang dapat kita ambil adalah kongruen $N, N-1, \ldots, 1 \bmod (N+1)$. Maka kita dapat mengambil benda sehingga banyaknya benda yang tersisa untuk lawan kongruen $0 \bmod (N+1)$. Misalkan, jika lawan mengambil 1 benda, maka kita harus mengambil sebanyak $N$ benda, jika lawan mengambil 2 benda, maka kita harus mengambil $N-1$ benda dan seterusnya, jika lawan mengambil $N$ benda, maka kita harus mengambil 1 benda. Jadi, kita selalu bisa menyisakan benda sedemikian sehingga sisa benda kongruen $0 \bmod (N+1)$ bagi lawan. Jika proses ini dilakukan terus menerus, pada akhirnya akan tersisa $N+1$ benda untuk lawan. Kita tahu lawan akan mengambil sebanyak $1,2,3, \ldots$, atau $N$ benda. Oleh karena itu, sisa benda yang tersedia untuk kita adalah $N, N-1, \ldots$, atau 1 . Karena banyaknya benda yang dapat diambil adalah sebanyak maksimum $N$, maka kita dapat mengambil semua benda yang tersisa, sehingga kita sebagai pemain pertama adalah pemenangnya.

2. Kasus $N+1 \mid M(N+1$ membagi $M)$

Dalam kasus ini, pemain kedua akan memenangkan permainan. Sebagai giliran kedua, pemain lawan akan menyisakan sisa benda yang kongruen $N, N-1, \ldots, 1 \bmod (N+1)$, maka kita dapat mengambil benda sehingga banyaknya benda yang tersisa untuk lawan kongruen $0 \bmod (N+1)$. Kita tahu lawan akan mengambil benda sebanyak $1,2,3, \ldots, N$. Oleh karena itu, sisa benda yang tersedia untuk kita kongruen $N, N-1, \ldots, 1 \bmod (N+1)$, maka kita dapat 
mengambil benda sehingga banyaknya benda yang tersisa untuk lawan kongruen $0 \bmod (N+1)$. Misalkan, jika lawan mengambil 1 benda, maka kita harus mengambil sebanyak $N$ benda, jika lawan mengambil 2 benda, maka kita harus mengambil $N-1$ benda dan seterusnya, jika lawan mengambil $N$ benda, maka kita harus mengambil 1 benda. Jadi, kita selalu bisa menyisakan benda sedemikian sehingga sisa benda kongruen $0 \bmod (N+1)$ bagi lawan. Jika proses ini dilakukan terus menerus, pada akhirnya akan tersisa $N+1$ benda untuk lawan. Kita tahu lawan akan mengambil sebanyak $1,2,3, \ldots$, atau $N$ benda. Oleh karena itu, sisa benda yang tersedia untuk kita adalah $N, N-1, \ldots$, atau 1 . Karena banyaknya benda yang dapat diambil adalah sebanyak maksimum $N$, maka kita dapat mengambil semua benda yang tersisa, sehingga kita sebagai pemain kedua adalah pemenangnya.

Tabel 3. Ilustrasi Permainan NIM Maksima 21 Benda dengan Pemain Terakhir yang Mengambil Sisa Benda adalah Pemain yang Kalah (A Mulai Dahulu, B sebagai Pemenang)

\begin{tabular}{|c|c|c|c|}
\hline \multicolumn{2}{|c|}{ A } & \multicolumn{2}{|c|}{ B } \\
\hline Benda diambil & Sisa benda & Benda diambil & Sisa benda \\
\hline 1 & 20 & 3 & 17 \\
\hline 2 & 15 & 2 & 13 \\
\hline 1 & 12 & 3 & 9 \\
\hline 3 & 6 & 1 & 5 \\
\hline 2 & 3 & 2 & 1 \\
\hline 1 & 0 & & \\
\hline
\end{tabular}

Dari 21 benda, A sebagai pemain pertama mengambil 1 benda, sehingga tersisa 20 benda. B sebagai pemain kedua mengambil 3 benda sehingga sisa benda menjadi 17. Demikian seterusnya dapat dilihat pada Tabel 3 bahwa pemain B memenangkan permainan.

Tabel 4. Ilustrasi Permainan NIM Maksima 20 Benda dengan Pemain Terakhir yang Mengambil Sisa Benda adalah Pemain yang Kalah (A Mulai Dahulu, A sebagai Pemenang)

\begin{tabular}{|c|c|c|c|}
\hline \multicolumn{2}{|c|}{ A } & \multicolumn{2}{|c|}{ B } \\
\hline Benda diambil & Sisa benda & Benda diambil & Sisa benda \\
\hline 1 & 19 & 3 & 16 \\
\hline 3 & 13 & 1 & 12 \\
\hline 3 & 9 & 1 & 8 \\
\hline 3 & 5 & 1 & 4 \\
\hline 3 & 1 & 1 & 0 \\
\hline
\end{tabular}

Dari 20 benda, A sebagai pemain pertama mengambil 1 benda, sehingga tersisa 19 benda. B sebagai pemain kedua mengambil 3 benda sehingga sisa benda menjadi 16. Demikian seterusnya dapat dilihat pada Tabel 4 bahwa pemain A memenangkan permainan.

Dari kedua ilustrasi di atas, akan dibentuk suatu strategi untuk memenangkan permainan NIM Maksima dengan pemain terakhir yang mengambil sisa benda adalah pemain yang kalah. Perhatikan 2 kasus berikut ini.

1. Kasus $M \not \equiv 1 \bmod (N+1)$

Dalam kasus ini, pemain pertama akan memenangkan permainan. Sebagai 
giliran pertama, kita dapat mengambil benda sehingga banyaknya benda yang tersisa adalah kongruen $1 \bmod (N+1)$. Kita tahu lawan akan mengambil sebanyak $1,2,3, \ldots, N$ benda. Sisa benda yang tersedia yang dapat kita ambil adalah kongruen $(N+1), N, \ldots, 2 \bmod (N+1)$. Maka kita dapat mengambil benda sehingga banyaknya benda yang tersisa untuk lawan kongruen $1 \bmod (\mathrm{N}+$ 1). Misalkan, jika lawan mengambil 1 benda, maka kita harus mengambil sebanyak $N$ benda, jika lawan mengambil 2 benda, maka kita harus mengambil $N-1$ benda dan seterusnya, jika lawan mengambil $N$ benda, maka kita harus mengambil 1 benda. Jadi, kita selalu bisa menyisakan benda sedemikian sehingga sisa benda kongruen $1 \bmod (N+1)$ bagi lawan. Jika proses ini dilakukan terus menerus, pada akhirnya akan tersisa $N+2$ benda untuk lawan. Kita tahu lawan akan mengambil sebanyak $1,2,3, \ldots$, atau $N$ benda. Oleh karena itu, sisa benda yang tersedia untuk kita adalah $N+1, N, \ldots$, atau 2 . Karena banyaknya benda yang dapat diambil adalah sebanyak maksimum $N$, maka kita dapat mengambil banyaknya benda sehingga tersisa 1 benda bagi lawan, sehingga kita sebagai pemain pertama adalah pemenangnya.

2. Kasus $M \equiv 1 \bmod (N+1)$

Dalam kasus ini, pemain kedua akan memenangkan permainan. Sebagai giliran kedua, pemain lawan akan menyisakan sisa benda yang kongruen $(\mathrm{N}+$ $1), N, \ldots, 2 \bmod (N+1)$ maka kita dapat mengambil benda sehingga banyaknya benda yang tersisa untuk lawan kongruen $1 \bmod (N+1)$. Kita tahu lawan akan mengambil benda sebanyak $1,2,3, \ldots, N$. Oleh karena itu, sisa benda yang tersedia untuk kita kongruen $(N+1), N, \ldots, 2 \bmod (N+1)$, maka kita dapat mengambil benda sehingga banyaknya benda yang tersisa untuk lawan kongruen $1 \bmod (N+$ 1). Misalkan, jika lawan mengambil 1 benda, maka kita harus mengambil sebanyak $N$ benda, jika lawan mengambil 2 benda, maka kita harus mengambil $N-1$ benda dan seterusnya, jika lawan mengambil $N$ benda, maka kita harus mengambil 1 benda. Jadi, kita selalu bisa menyisakan benda sedemikian sehingga sisa benda kongruen $1 \bmod (N+1)$ bagi lawan. Jika proses ini dilakukan terus menerus, pada akhirnya akan tersisa $N+2$ benda untuk lawan. Kita tahu lawan akan mengambil sebanyak $1,2,3, \ldots$, atau $N$ benda. Oleh karena itu, sisa benda yang tersedia untuk kita adalah $N+1, N, \ldots$, atau 2 . Karena banyaknya benda yang dapat diambil adalah sebanyak maksimum $N$, maka kita dapat mengambil banyaknya benda sehingga tersisa 1 benda bagi lawan, sehingga kita sebagai pemain kedua adalah pemenangnya.

\section{Strategi Kemenangan NIM Satu-Empat}

Misalkan kita memiliki $M$ benda dan banyaknya pengambilan benda adalah sebanyak 1 atau 4 buah benda. Terdapat dua pemain (namakanlah pemain A dan B) dengan 30 benda tersedia di atas meja. Setiap pemain pada gilirannya hanya boleh mengambil 1 atau 4 buah benda. Permainan dimenangkan oleh orang yang paling terakhir mengambil sisa benda. Untuk variasi permainan dimana pemain terakhir yang mengambil sisa benda adalah pemain yang kalah, kami belum menemukan strategi untuk memenangkan permainan tersebut karena banyaknya pola permainan yang dapat dilakukan. 
Tabel 5. Ilustrasi Permainan NIM Satu-Empat 28 Benda dengan Pemain Terakhir yang Mengambil Sisa Benda adalah Pemain yang Menang (A Mulai Dahulu, A sebagai Pemenang)

\begin{tabular}{|c|c|c|c|}
\hline \multicolumn{2}{|c|}{$\mathrm{A}$} & \multicolumn{2}{|c|}{$\mathrm{B}$} \\
\hline Benda diambil & Sisa benda & Benda diambil & Sisa benda \\
\hline 1 & 27 & 4 & 23 \\
\hline 1 & 22 & 4 & 18 \\
\hline 1 & 17 & 1 & 16 \\
\hline 1 & 15 & 4 & 11 \\
\hline 4 & 7 & 1 & 6 \\
\hline 1 & 5 & 4 & 1 \\
\hline 1 & 0 & & \\
\hline
\end{tabular}

Dari 28 benda, A sebagai pemain pertama mengambil 1 benda, sehingga tersisa 27 benda. B sebagai pemain kedua mengambil 4 benda sehingga sisa benda menjadi 23. Demikian seterusnya dapat dilihat pada Tabel 5 bahwa pemain A memenangkan permainan.

Tabel 6. Ilustrasi Permainan NIM Satu-Empat 30 Benda dengan Pemain Terakhir yang Mengambil Sisa Benda adalah Pemain yang Menang (A Mulai Dahulu, B sebagai Pemenang)

\begin{tabular}{|c|c|c|c|}
\hline \multicolumn{2}{|c|}{$\mathrm{A}$} & \multicolumn{2}{|c|}{ B } \\
\hline Benda diambil & Sisa benda & Benda diambil & Sisa benda \\
\hline 4 & 26 & 4 & 22 \\
\hline 4 & 18 & 1 & 17 \\
\hline 1 & 16 & 1 & 15 \\
\hline 4 & 11 & 4 & 7 \\
\hline 1 & 6 & 1 & 5 \\
\hline 4 & 1 & 1 & 0 \\
\hline
\end{tabular}

Dari 30 benda, A sebagai pemain pertama mengambil 4 benda, sehingga tersisa 26 benda. B sebagai pemain kedua mengambil 4 benda sehingga sisa benda menjadi 22. Demikian seterusnya dapat dilihat pada Tabel 6 bahwa pemain B memenangkan permainan.

Sekarang, perhatikan 2 kasus berikut ini.

I. Jika $M \equiv 1,3,4 \bmod 5$, maka pemenangnya adalah pemain pertama.

Tulis $M=5 k+l$, untuk $l=1,3,4$ dan $k \in \mathbb{N}$. Sebagai pemain pertama, kita harus mengambil benda sedemikian sehingga sisa benda yang dapat diambil oleh lawan adalah kongruen $0,2 \bmod 5$. Akan dibuktikan untuk setiap $M \equiv$ $1,3,4 \bmod 5$, pemain pertama akan selalu bisa menyisakan benda yang kongruen $0,2 \bmod 5$ bagi lawan.

Tabel 7. Tabel Pola Kemenangan Pemain Pertama

\begin{tabular}{lllllllllll}
\hline Banyaknya benda & 1 & 2 & 3 & 4 & 5 & 6 & 7 & 8 & 9 & 10 \\
\hline $\mathrm{K}=$ kalah, $\mathrm{M}=$ menang & $\mathrm{M}$ & $\mathrm{K}$ & $\mathrm{M}$ & $\mathrm{M}$ & $\mathrm{K}$ & $\mathrm{M}$ & $\mathrm{K}$ & $\mathrm{M}$ & $\mathrm{M}$ & $\mathrm{K}$ \\
\hline
\end{tabular}

Kita pandang 3 kasus berikut ini:

1. Kasus $M=5 k+1$

Jika banyaknya benda yang diambil adalah 1 , maka sisanya $0 \bmod 5$, sedangkan jika banyaknya benda yang diambil adalah 4 , maka sisanya 
$2 \bmod 5$. Sehingga banyak benda yang diambil boleh 1 atau 4 .

2. Kasus $M=5 k+3$

Jika banyaknya benda yang diambil adalah 1 , maka sisanya $2 \bmod 5$, sedangkan jika banyaknya benda yang diambil adalah 4, maka sisanya $4 \bmod 5$. Sehingga banyak benda yang diambil hanya boleh 1 .

3. Kasus $M=5 k+4$

Jika banyaknya benda yang diambil adalah 1 , maka sisanya $3 \bmod 5$, sedangkan jika banyaknya benda yang diambil adalah 4, maka sisanya 0 mod 5. Sehingga banyak benda yang diambil hanya boleh 4 .

II. Jika $M \equiv 0,2 \bmod 5$, maka pemenangnya adalah pemain kedua.

Tulis $M=5 k+l$, untuk $l=0,2$ dan $k \in \mathbb{N}$. Sebagai pemain kedua, kita harus mengambil benda sedemikian sehingga sisa benda yang dapat diambil oleh lawan adalah kongruen 0,2 $\bmod 5$. Akan dibuktikan untuk setiap $M \equiv 0,2 \bmod 5$, pemain pertama selalu bisa menyisakan pemain kedua sisa benda yang kongruen $1,3,4 \bmod 5$.

Kita pandang 2 kasus berikut ini:

1. Kasus $M=5 k$

Jika banyaknya benda yang diambil adalah 1 , maka sisanya $4 \bmod 5$, sedangkan jika banyaknya benda yang diambil adalah 4 , maka sisanya 1 mod 5. Maka dari kasus ini, pemain kedua berada pada posisi menang.

2. Kasus $M=5 k+2$

Jika banyaknya benda yang diambil adalah 1 , maka sisanya $1 \bmod 5$, sedangkan jika banyaknya benda yang diambil adalah 4, maka sisanya 3 mod 5. Maka dari kasus ini, pemain kedua berada pada posisi menang.

\section{Strategi Kemenangan NIM Satu-Tiga-Empat}

Misalkan kita memiliki $M$ benda dengan banyaknya pengambilan benda adalah sebanyak 1,3, atau 4 buah benda. Terdapat dua pemain (namakanlah pemain A dan B) dengan 30 benda tersedia di atas meja. Setiap pemain pada gilirannya hanya boleh mengambil 1, 3, atau 4 buah benda. Permainan dimenangkan oleh orang yang paling terakhir mengambil sisa benda. Untuk variasi permainan dimana pemain terakhir yang mengambil sisa benda adalah pemain yang kalah, kami belum dapat menemukan strategi untuk memenangkan permainan tersebut karena banyaknya pola permainan yang dapat dilakukan.

Tabel 8. Ilustrasi Permainan NIM Satu-Tiga-Empat 27 Benda dengan Pemain Terakhir yang Mengambil Sisa Benda adalah Pemain yang Menang (A Mulai Dahulu, A sebagai Pemenang)

\begin{tabular}{|c|c|c|c|}
\hline \multicolumn{2}{|c|}{ A } & \multicolumn{2}{|c|}{ B } \\
\hline Benda diambil & Sisa benda & Benda diambil & Sisa benda \\
\hline 4 & 23 & 4 & 19 \\
\hline 3 & 16 & 1 & 15 \\
\hline 1 & 14 & 1 & 13 \\
\hline 4 & 9 & 1 & 8 \\
\hline 1 & 7 & 1 & 6 \\
\hline 4 & 2 & 1 & 1 \\
\hline 1 & 0 & & \\
\hline
\end{tabular}


Dari 27 benda, A sebagai pemain pertama mengambil 1 benda, sehingga tersisa 23 benda. B sebagai pemain kedua mengambil 4 benda sehingga sisa benda menjadi 19. Selanjutnya, dapat dilihat pada Tabel 8 bahwa pemain A memenangkan permainan.

Tabel 9. Ilustrasi Permainan NIM Satu-Tiga-Empat 28 Benda dengan Pemain Terakhir yang Mengambil Sisa Benda adalah Pemain yang Menang (A Mulai Dahulu, B sebagai Pemenang)

\begin{tabular}{cccc}
\hline & A & & B \\
\hline Benda diambil & Sisa benda & Benda diambil & Sisa benda \\
1 & 27 & 4 & 23 \\
4 & 19 & 3 & 16 \\
1 & 15 & 1 & 14 \\
3 & 11 & 4 & 7 \\
1 & 6 & 4 & 2 \\
1 & 1 & 1 & 0 \\
\hline
\end{tabular}

Dari 28 benda, A sebagai pemain pertama mengambil 1 benda, sehingga tersisa 27 benda. B sebagai pemain kedua mengambil 4 benda sehingga sisa benda menjadi 23. Selanjutnya, dapat dilihat pada Tabel 9 bahwa pemain B memenangkan permainan.

Perhatkan 2 kasus berikut ini.

I. Jika $M \equiv 1,3,4,5,6 \bmod 7$, maka pemenangnya adalah pemain pertama.

Tulis $M=5 k+l$, untuk $l=1,3,4,5,6$ dan $k \in \mathbb{N}$. Sebagai pemain pertama, kita harus mengambil benda sedemikian sehingga sisa benda yang dapat diambil oleh lawan adalah kongruen 0,2 mod 5. Akan dibuktikan untuk setiap $M \equiv 1,3,4,5,6 \bmod 5$, pemain pertama selalu bisa menyisakan benda yang kongruen $0,2 \bmod 5$ bagi lawan.

Tabel 10. Tabel Pola Kemenangan Pemain Pertama

\begin{tabular}{lllllllllll}
\hline Banyaknya benda & 1 & 2 & 3 & 4 & 5 & 6 & 7 & 8 & 9 & 10 \\
\hline $\mathrm{K}=$ kalah, $\mathrm{M}=$ menang & $\mathrm{M}$ & $\mathrm{K}$ & $\mathrm{M}$ & $\mathrm{M}$ & $\mathrm{M}$ & $\mathrm{M}$ & $\mathrm{K}$ & $\mathrm{M}$ & $\mathrm{K}$ & $\mathrm{M}$ \\
\hline
\end{tabular}

Kita pandang 5 kasus berikut ini.

1. Kasus $M=7 k+1$

Jika banyaknya benda yang diambil adalah 1 , maka sisanya $0 \bmod 7$, jika banyaknya benda yang diambil adalah 3 , maka sisanya $4 \bmod 7$, sedangkan jika banyaknya benda yang diambil adalah 4, maka sisanya 3 mod 7. Sehingga banyaknya benda yang diambil untuk kasus ini hanya boleh 1 .

2. Kasus $M=7 k+3$

Jika banyaknya benda yang diambil adalah 1 , maka sisanya $2 \bmod 7$, jika banyaknya benda yang diambil adalah 3 , maka sisanya $0 \bmod 7$, sedangkan jika banyaknya benda yang diambil adalah 4 , maka sisanya $6 \bmod 7$. Sehingga banyaknya benda yang diambil boleh 1 atau 3 .

3. Kasus $M=7 k+4$

Jika banyaknya benda yang diambil adalah 1 , maka sisanya $3 \bmod 7$, jika banyaknya benda yang diambil adalah 3 , maka sisanya $1 \bmod 7$, sedangkan jika banyaknya benda yang diambil adalah 4, maka sisanya 
$0 \bmod 7$. Sehingga banyaknya benda yang diambil untuk kasus ini hanya boleh 4.

4. Kasus $M=7 k+5$

Jika banyaknya benda yang diambil adalah 1 , maka sisanya $4 \bmod 7$, jika banyaknya benda yang diambil adalah 3 , maka sisanya $2 \bmod 7$, sedangkan jika banyaknya benda yang diambil adalah 4, maka sisanya $1 \bmod 7$. Sehingga banyaknya benda yang diambil untuk kasus ini hanya boleh 3.

5. Kasus $M=7 k+6$

Jika banyaknya benda yang diambil adalah 1 , maka sisanya $5 \bmod 7$, jika banyaknya benda yang diambil adalah 3 , maka sisanya $3 \bmod 7$, sedangkan jika banyaknya benda yang diambil adalah 4 , maka sisanya 2 mod 7. Sehingga banyaknya benda yang diambil untuk kasus ini hanya boleh 4 .

II. Jika $M \equiv 0,2 \bmod 7$, maka pemenangnya adalah pemain kedua.

Tulis $M=7 k+l$, untuk $l=0,2$ dan $k \in \mathbb{N}$. Sebagai pemain kedua, kita harus mengambil benda sedemikian sehingga sisa benda yang dapat diambil oleh lawan adalah kongruen $0,2 \bmod 7$. Akan dibuktikan untuk setiap $M \equiv 0,2 \bmod 7$, pemain pertama selalu bisa menyisakan pemain kedua sisa benda yang kongruen $1,3,4,5,6 \bmod 7$.

Kita pandang 2 kasus berikut ini:

1. Kasus $M=7 k$

Jika banyaknya benda yang diambil adalah 1, maka sisanya $6 \bmod 7$, jika banyaknya benda yang diambil adalah 3, maka sisanya $4 \bmod 7$, sedangkan jika banyaknya benda yang diambil adalah 4 , maka sisanya $3 \bmod 7$. Dari kasus ini, pemain kedua berada pada posisi menang.

2. Kasus $M=7 k+2$

Jika banyaknya benda yang diambil adalah 1 , maka sisanya $1 \bmod 7$, jika banyaknya benda yang diambil adalah 3, maka sisanya $6 \bmod 7$, sedangkan jika banyaknya benda yang diambil adalah 4, maka sisanya $5 \bmod 7$. Dari kasus ini, pemain kedua berada pada posisi menang.

\section{Strategi Kemenangan NIM Satu-Tiga-Lima-Tujuh}

Terdapat dua pemain (namakanlah pemain A dan B) dengan 16 benda tersedia di atas meja dengan baris pertama memiliki 1 benda, baris kedua memiliki 3 benda, baris ketiga memiliki 5 benda, dan baris keempat memiliki 7 benda. Setiap pemain pada gilirannya dapat mengambil benda pada salah satu baris pertama, kedua, ketiga, ataupun keempat dengan banyaknya pengambilan minimal 1 dan maksimal adalah sisa semua benda yang terdapat pada baris tersebut. Pemain tidak diperbolehkan mengambil benda dalam dua baris yang berbeda pada giliran yang sama. Pemain terakhir yang mengambil sisa benda terakhir adalah pemain yang kalah.

Dalam permainan ini, kita katakan seseorang dalam posisi kalah jika penjumlahan biner bernilai 0, sehingga dalam permainan ini kita harus meninggalkan penjumlahan biner bernilai 0 kepada lawan. Penjumlahan biner adalah banyaknya bilangan yang tak memiliki pasangan ketika kita sudah mengubah suatu bilangan menjadi kelipatan empat, dua, dan satu. Kita harus 
menghitung terlebih dahulu setiap benda di baris tersebut dan kita ubah dalam kelipatan 4, 2, dan 1 sehingga dapat kita lihat penjumlahan biner pada baris-baris tersebut adalah seperti pada Gambar 1 .

\begin{tabular}{|c|c|c|}
\hline Baris $1=1$ & $=1 \times 1$ & $=$ \\
\hline Baris $2=3$ & $=1 \times 2+1 \times 1$ & $=z$ \\
\hline Baris $3=5$ & $=1 \times 4+1 \times 1$ & $=4$ \\
\hline Baris $4=7$ & $=1 \times 4+1 \times 2+1 \times 1$ & $=4 z$ \\
\hline \multicolumn{2}{|c|}{ Banyaknya yang tak memiliki pasangan } & $=\begin{array}{lll}0 & 0\end{array}$ \\
\hline
\end{tabular}

Gambar 1. Penjumlahan Biner dengan Mengubah Menjadi Kelipatan 4, 2, dan 1

Seperti yang dapat kita lihat, terdapat dua kelipatan "4", dua kelipatan "2", dan empat kelipatan "1" sehingga kita memiliki sebanyak dua+dua+empat=delapan kelipatan, kita mempunyai sebanyak genap kelipatan yaitu delapan yang jika dibagi 2 mempunyai sisa bagi 0 . Untuk memenangkan permainan NIM ini, kita harus selalu bergerak meninggalkan musuh penjumlahan biner bernilai 0, yaitu selalu dapat pasangan kelipatan 4, pasangan kelipatan 2, dan pasangan kelipatan 1 dan tidak ada yang tidak berpasangan. Jika tidak, lawan kita memiliki kedudukan dengan posisi menang dan kita harus bergantung kepada kecerobohan musuh jika kita ingin menang.

Berikut adalah contoh simulasi cara meninggalkan penjumlahan biner lawan bernilai 0 . Misalkan pada awal permainan, lawan mengambil 2 benda pada baris ke 4, sehingga kita dapat menuliskan konfigurasi benda tersebut menjadi seperti pada Gambar 2.

\begin{tabular}{|c|c|}
\hline Baris $1=1$ & $=1 \times 1$ \\
\hline Baris $2=3$ & $=1 \times 2+1 \times 1$ \\
\hline Baris $3=5$ & $=1 \times 4+1 \times 1$ \\
\hline Baris $4=5$ & $=1 \times 4+1 \times 1$ \\
\hline \multicolumn{2}{|c|}{ Banyaknya yang tak memiliki pasangan } \\
\hline
\end{tabular}

Gambar 2. Contoh Konfigurasi Benda pada NIM Satu-Tiga-Lima-Tujuh

Ambil satu "2" dengan cara mengambil 2 benda dari baris ke 2 sehingga kita meninggalkan lawan dengan konfigurasi 1, 1, 5, 5 yang bagi lawan adalah posisi kalah karena penjumlahan biner lawan sekarang bernilai 0 yaitu selalu dapat pasangan kelipatan 4, pasangan kelipatan 2, dan pasangan kelipatan 1 dan tidak ada yang tidak berpasangan. 


$\begin{array}{llll}\text { Baris } 1=1 & =1 \times 1 & = & 4 \\ \text { Baris } 2=1 & =1 \times 1 & = & 4 \\ \text { Baris } 3=5 & =1 \times 4+1 \times 1 & =4 & 4 \\ \text { Baris } 4=5 & =1 \times 4+1 \times 1 & =4 & \\ \text { Banyaknya yang tak memiliki pasangan } & =0 & 0 & 0\end{array}$

Gambar 3. Hasil Penjumlahan Biner dari Konfigurasi Gambar [2]

Setiap kali kita meninggalkan lawan dengan konfigurasi penjumlahan biner bernilai 0, maka kita memiliki kesempatan untuk menang lebih besar. Gambar 4 adalah contoh konfigurasi penjumlahan biner yang bernilai 0 .

\begin{tabular}{|c|c|c|}
\hline \multicolumn{2}{|c|}{ Konfigurasi penjumlahan biner bernilai 0} \\
\hline Empat Baris & Tiga Baris & Dua Baris \\
\hline $7,4,2,1$ & $7,5,2$ & 5,5 \\
\hline $6,5,2,1$ & $7,4,3$ & 4,4 \\
$6,4,3,1$ & $6,5,3$ & 3,3 \\
$5,5,1,1$ & $6,4,2$ & 2,2 \\
$4,4,1,1$ & $5,4,1$ & \\
$3,3,1,1$ & $3,2,1$ & \\
$2,2,1,1$ & $1,1,1$ & \\
\hline
\end{tabular}

\section{SIMPULAN}

Berdasarkan hasil pembahasan di atas, diperoleh beberapa kesimpulan sebagai berikut:

1. Strategi kemenangan untuk permainan NIM Maksima adalah sebagai berikut:

a. NIM Maksima dengan pemain terakhir yang mengambil sisa benda adalah pemain yang menang:

i. Jika $N+1 \nmid M$, maka pemain pertama yang menang

ii. Jika $N+1 \mid M$, maka pemain kedua yang menang.

b. NIM Maksima dengan pemain terakhir yang mengambil sisa benda adalah pemain yang kalah:

i. Jika $M \not \equiv 1 \bmod (N+1)$, maka pemain pertama yang menang

ii. Jika $M \equiv 1 \bmod (N+1)$, maka pemain kedua yang menang

2. Strategi kemenangan untuk permainan NIM Satu-Empat adalah sebagai berikut:

a. Jika $M \equiv 1,3,4 \bmod 5$, maka pemenangnya adalah pemain pertama

b. Jika $M \equiv 0,2 \bmod 5$, maka pemenangnya adalah pemain kedua 
3. Strategi kemenangan untuk permainan NIM Satu-Tiga-Empat adalah sebagai berikut:

a. Jika $M \equiv 1,3,4,5,6 \bmod 7$, maka pemenangnya adalah pemain pertama

b. Jika $M \equiv 0,2 \bmod 7$, maka pemenangnya adalah pemain kedua

4. Strategi kemenangan untuk permainan NIM Satu-Tiga-Lima-Tujuh adalah selalu membuat penjumlahan biner 0 bagi lawan.

Semua permainan NIM ini dapat dikembangkan dengan memvariasikan banyaknya pengambilan benda.

\section{DAFTAR RUJUKAN}

Arifin, M. (2010). Pembuatan Game NIM Menggunakan Alpha-beta Pruning. Laporan Penelitian. Surabaya: EEPIS-ITS.

Burcham, S. (2013). (Online),

(http://www.mcm.edu/mathdept/Shalisa_Sites_Burcham_2013.pdf, diakses 21 Juni 2015).

Burton, D. (2010). Elementary Number Theory. McGraw-Hill.

Silbernick, Z. \& Campbell, R. (2015). A Winning Strategy for The Game of Antonim. OALib Journal, (Online), (http://www.oalib.com/paper/3988826\#.V8aUb_19600, diakses 21 Agustus 2015). 